\title{
AC 2010-368: TEACHING LINEAR SYSTEMS USING MASTERY INSTRUCTION
}

Anthony Richardson, University of Evansville 


\title{
Teaching Linear Systems Using Mastery Instruction
}

\begin{abstract}
In the mastery instruction method ${ }^{1}$, students are required to demonstrate knowledge of a particular topic or group of topics before moving on to new topics. Results indicate that students learn more from a mastery course than they do from traditional courses. Self-paced instruction courses are the most well-known type of mastery course, but they can be ineffective when the university requires courses to be completed by semester's end. An alternative, the instructorpaced mastery course, attempts to satisfy university requirements that course grades be submitted in a timely manner while still providing most of the learning benefits of self-paced instruction.

In this paper, the author's experience with using instructor-paced mastery instruction to teach a Junior level course in Linear Systems and Signals is described. Results from student surveys demonstrate that students do indeed learn more from this style of instruction, but they also indicate areas of student dissatisfaction. The results from the surveys are presented and discussed. Lessons learned by the author are recounted and suggestions for improving the way in which mastery instruction was implemented in this course are presented.
\end{abstract}

\section{Introduction}

Undergraduate electrical and computer engineering and computer students at the University of Evansville are required to take a 3 credit course in Linear Systems. This course is typically taken during the Junior year. Here is the course description from the University catalog:
EE 310 Linear Systems (3) Provides a unified treatment of continuous-time and discrete-time linear signals and systems. Topics include introduction to the mathematical representation of signals, system characterization, convolution and system analysis in the time and frequency domains using differential equations, state-vector equations and transform techniques. Fourier, Laplace, $Z$ and discrete-Fourier transform techniques of signal and system analysis presented.

Prerequisite courses are Circuits II and Differential Equations.

The author participated in a weekly teaching discussion which used the book Teaching Engineering by Wankat and Oreovicz ${ }^{1}$ as a text to prompt discussion. After reading and discussing the section on mastery instruction, the author decided to teach the Linear Systems course using instructor-paced mastery instruction.

There are a variety of ways in which an instructor-paced mastery course can be implemented. In all variations students take regular examinations that are marked as "Mastered" or "Not Mastered". Grades can be determined based on the score on a final examination or based on mastering the regular exams.

The method implemented by the author is a slight variation to a method used by Wankat and described in Wankat and Oreovicz ${ }^{1}$. The course material was divided into eight core and two 
advanced modules. The modules corresponded closely with chapters from the textbook that was used $^{2}$.

The grade for the course was based on exams, homework, and projects. Grades were assigned as shown in Table 1. The eight core modules are denoted $\mathrm{C} 1-\mathrm{C} 8$ while the two advanced modules are denoted $\mathrm{A} 1$ and $\mathrm{A} 2$.

\begin{tabular}{|c|l|l|l||}
\hline Grade & Modules & Homework & Projects \\
\hline \hline D & $\begin{array}{l}\text { Mastery of four of eight } \\
\text { core modules (C1-C8). }\end{array}$ & $\begin{array}{l}\text { Complete six of eight (C1- } \\
\text { C8) homework assignments }\end{array}$ & $\begin{array}{l}\text { Satisfactory completion of } \\
\text { two laboratory projects }\end{array}$ \\
\hline C & $\begin{array}{l}\text { Mastery of six of eight core } \\
\text { modules (C1-C8). }\end{array}$ & $\begin{array}{l}\text { Complete all (C1-C8) } \\
\text { homework assignments }\end{array}$ & $\begin{array}{l}\text { Satisfactory completion of } \\
\text { four laboratory projects }\end{array}$ \\
\hline B & $\begin{array}{l}\text { Mastery of all eight core } \\
\text { modules (C1-C8) }\end{array}$ & $\begin{array}{l}\text { Complete all C1-C8, A1-A2 } \\
\text { homework }\end{array}$ & $\begin{array}{l}\text { Satisfactory completion of } \\
\text { six laboratory projects }\end{array}$ \\
\hline A & $\begin{array}{l}\text { Mastery of all core (C1 -C8) } \\
\text { and advanced (A1-A2) }\end{array}$ & $\begin{array}{l}\text { Complete of all C1-C8, A1- } \\
\text { A2 homework }\end{array}$ & $\begin{array}{l}\text { Satisfactory completion of } \\
\text { eight laboratory projects }\end{array}$ \\
\hline
\end{tabular}

Table 1: Assignment of Grades

Mastery of a module was demonstrated by passing a corresponding exam. All exams were graded on a pass/fail basis and no percentage scores were given. Demonstrating mastery of a module (passing the exam) was approximately equivalent to scoring $85 \%$ or higher on the exam if standard scoring were used. The actual grading scale included plus or minus course grades (B+, A-, etc). These were given if more or less work than described in the table above was completed.

The class met three hours per week. During non-exam periods, class time was used to answer questions, work examples and introduce new topics. Students were encouraged to read the textbook outside of the class period in order to learn course concepts. There were 25 students taking the course.

\section{Modules}

Selecting appropriately sized modules is critical. A module needs to contain enough material for an exam and yet not so much that students are overwhelmed. In this course each module corresponded (approximately) to a (four to six section) chapter in the textbook. Naturally in other courses a module might only cover $1 / 2$ a chapter or might cover as much as two chapters.

Table 2 lists the modules in the course. They are listed in the order in which the module was covered in the course. The course covered the material in the first twelve chapters of the text. Chapter 1 was an introductory chapter and material from that chapter was not included in any of the modules. 


\begin{tabular}{|c|l|c|}
\hline Module & Description & Lecture Periods \\
\hline C1 & Continuous Time Signals and Systems (Chapter 2) & 4 \\
\hline C2 & Linear Time Invariant Systems (Chapter 3) & 4 \\
\hline C3 & Fourier Series (Chapter 4) & 4 \\
\hline C4 & The Fourier Transform (Chapter 5) & 5 \\
\hline A1 & Applications of the Fourier Transform (Chapter 6) & 4 \\
\hline C5 & The Laplace Transform (Chapter 7) & 4 \\
\hline C6 & Discrete Time Signals, Systems (Chapters 9 and 10) & 5 \\
\hline C7 & The z-Transform (Chapter 11) & 4 \\
\hline C8 & Fourier Transforms of Discrete Time Signals (Chapter 12) & 4 \\
\hline A2 & State Variables and Continuous Time Systems (Chapter 8) & 4 \\
\hline
\end{tabular}

Table 2: Course Modules (Chronological Order)

The number of core and advanced modules should be given careful consideration. A total of 10 to 12 modules seems appropriate for a semester course. It is not necessary to designate any of the modules as advanced. Depending on program requirements, a strong argument can be made that the material in Chapters 6 and 8 should be considered core to the course. Having an advanced module in the middle of the core modules allowed some students to use that week to concentrate on core modules that they had not previously mastered.

The number of lecture periods alloted to each module is listed in Table 2. One of the lecture periods for each module was used as an exam period. There is a total of 42 lecture periods listed in Table 2. This is the number of periods available during a typical semester at the University of Evansville.

\section{Exams}

All students took all exams. The regularly scheduled exams were given during the normal class period. Exams were not marked with a percentage score. Instead, they were marked as either Mastered or Not Mastered. Exams could be retaken as many times as necessary in order to master the exam. Exam retake periods were scheduled outside of the normal class period. The course schedule simply did not permit students to retake exams during the normal period. Students were required to wait at least a week before retaking an exam. They were also required to completely rework a failed exam before being permitted to retake it. Students also had to give the instructor at least three days notice that they intended to retake an exam. Together these retake policies gave the students incentive to try to pass the test the first time, ensured that the students actually studied the exam topic between exams, and allowed the instructor time to make up a new exam.

The number of attempts necessary to pass an exam for a particular module is shown in Table 3. The majority of students Mastered a module on either the first or second attempt. No student make more than four attempts at mastery of a module. Approximately half the students in the 
class never mastered either of the two advanced modules.

The data in Table 3 suggests that it may be possible to modify the grading contract in Table 1 so that students are only allowed two or three attempts at passing a mastery exam. This would allow a majority of students to demonstrate mastery while significantly reducing the workload for the instructor.

\begin{tabular}{|c|c|c|c|c|c|}
\cline { 2 - 6 } \multicolumn{1}{c|}{} & \multicolumn{4}{c|}{ Number of Students Who Mastered Versus Attempt } \\
\hline Exam & $\begin{array}{c}\text { First } \\
\text { Attempt }\end{array}$ & $\begin{array}{c}\text { Second } \\
\text { Attempt }\end{array}$ & $\begin{array}{c}\text { Third } \\
\text { Attempt }\end{array}$ & $\begin{array}{c}\text { Fourth } \\
\text { Attempt }\end{array}$ & Never \\
\hline C1 & 13 & 9 & 2 & 1 & 0 \\
\hline C2 & 6 & 14 & 4 & & 1 \\
\hline C3 & 10 & 14 & & & 1 \\
\hline C4 & 6 & 13 & 4 & & 2 \\
\hline C5 & 5 & 10 & 2 & 7 & 1 \\
\hline C6 & 5 & 16 & 1 & 1 & 2 \\
\hline C7 & 13 & 6 & 2 & & 4 \\
\hline C8 & 19 & 4 & & & 2 \\
\hline A1 & 6 & 5 & 2 & 1 & 11 \\
\hline A2 & 8 & 4 & & & 13 \\
\hline
\end{tabular}

Table 3: Exam Attempts

\section{Homework}

Typically, two to five homework problems were assigned every class period. Three or four class assignments were grouped into a homework set and homework sets were collected on an approximately weekly basis. Students could work together on homework problems, but each student was required to turn in their own work. Late homework was normally not accepted.

\section{Projects}

The projects were MATLAB programming projects. Students were required to work individually on the MATLAB projects. A brief description of the projects is shown in Table 4. Complete projects can be obtained by contacting the author.

\section{Final Grades}

The distribution of final grades in the course is shown in Table 5. The grades are higher than when this course is taught in a more traditional manner. This can be attributed to a number of factors. Grades in mastery courses are usually higher than in nonmastery courses ${ }^{1,5}$. Most probably however, the grading contract in Table 1 is too easy. Limiting the number of exam attempts as suggested above would also lower the average final grade as well. 


\begin{tabular}{|c|l|}
\hline Project & Description \\
\hline \hline 1 & $\begin{array}{l}\text { Introduction to MATLAB: Matrix operations, sampling of continuous time } \\
\text { functions, plotting, complex numbers, polynomial evaluation. }\end{array}$ \\
\hline 2 & Scripts and functions: Script and function files, unit step and unit ramp functions. \\
\hline 3 & Fourier Series: Periodic signals and line spectra, truncated Fourier series. \\
\hline 4 & $\begin{array}{l}\text { Music Synthesis: Musical notes and frequencies, sampling of continuous tones, } \\
\text { audio playback. }\end{array}$ \\
\hline 5 & $\begin{array}{l}\text { Polynomial Representation: Polynomial multiplication via convolution, finding } \\
\text { zeros of a polynomial, partial fraction expansion. }\end{array}$ \\
\hline 6 & $\begin{array}{l}\text { Discrete-time systems: Using the conv and filter functions, FIR and IIR systems, } \\
\text { stable and unstable IIR systems. }\end{array}$ \\
\hline 7 & $\begin{array}{l}\text { Image Processing: Image formats, reading and display images, the conv2 and } \\
\text { filter2 functions. }\end{array}$ \\
\hline 8 & $\begin{array}{l}\text { Discrete Fourier Transforms: Using the fft function, convolution using the DFT, } \\
\text { interpolation in the frequency and time domains. }\end{array}$ \\
\hline
\end{tabular}

Table 4: MATLAB Projects

\begin{tabular}{|c|c|}
\hline Grade & Number of Students \\
\hline A & 12 \\
\hline B & 9 \\
\hline C & 3 \\
\hline D & 1 \\
\hline F & 0 \\
\hline
\end{tabular}

Table 5: Distribution of Final Grades

\section{Advantages of Instructor-Paced Mastery}

The primary advantage of an instructor-paced mastery course is that the students learn the material better than with traditional instruction. I truly believe that this is so and student survey results (presented later) suggest that students agree. I felt the students were trying harder and were putting more time into the course than they would if it were taught in the traditional manner.

Students claimed less test anxiety than with traditional instruction. This was, of course, due to the fact that students could retake an exam (multiple times if necessary) in order to master it.

Although the number of exams that need to be graded seems overwhelming, since they are not marked in the traditional manner (by assigning points to each problem) they can be graded very quickly. A large number of exams could be marked as either "Mastered" or "Not Mastered" with a quick scan of the exam. The borderline exams took a bit more time to grade. 


\section{Disadvantages of Instructor-Paced Master}

This method of teaching can be quite time consuming for the instructor, more so than for a traditional course. Much more time is spent creating exams. Although exams can be graded more quickly, many more exams meant that more time overall was probably spent grading. There are more regular exams than in a traditional course and additional time is required to create the exams for students who need to retake an exam.

\section{Student Evaluation of the Course}

The 25 students in the course completed the 12 question survey shown in Table 6 at the end of the semester. Student responses were on a five-level Likert scale with a 1 representing strong agreement with the statement and a 5 representing strong disagreement. A summary (mean and standard deviation) of the survey responses is also shown in Table 6.

Except for Question 6 students agreed with the statements on the survey. In general students felt that the learned more and had a better understanding of concepts than with traditional instruction. Students were neutral on question 6, indicating that some students felt that they knew the underlying concepts even though they did not Master the corresponding exam.

\section{Conclusion}

The method described here could be improved upon by limiting the number of times a student can retake an exam. This would reduce the amount of time spent by the instructor in creating exams and hopefully motivate students to study harder for both original and retake exams. It is not expected that this change would adversely affect the increase in student learning.

The instructor-paced mastery teaching method does require careful planning and is more time intensive for the instructor. However, the increases in student learning can make using the method very rewarding. 


\begin{tabular}{|c|c|c|c|}
\hline \multicolumn{2}{|c|}{ Question } & \multirow{2}{*}{\begin{tabular}{|c|} 
Mean \\
1.89
\end{tabular}} & \multirow{2}{*}{\begin{tabular}{|c|} 
Std Dev \\
0.58
\end{tabular}} \\
\hline & $\begin{array}{l}\text { I feel that I learned more in this course than I would have if a traditional } \\
\text { instructional method had been used. }\end{array}$ & & \\
\hline 2 & $\begin{array}{l}\text { I feel that I have a better understanding of course concepts than I would } \\
\text { have if a traditional instructional method had been used. }\end{array}$ & 1.94 & 0.64 \\
\hline 3 & $\begin{array}{l}\text { I feel that I am better prepared to solve problems than I would be if a } \\
\text { traditional instructional method had been used. }\end{array}$ & 2.11 & 0.68 \\
\hline 4 & $\begin{array}{l}\text { I feel that I put more effort into this course than I would have if a } \\
\text { traditional instructional method had been used. }\end{array}$ & 2.39 & 1.04 \\
\hline 5 & $\begin{array}{l}\text { In tests that I have mastered, I feel that I understand the corresponding } \\
\text { concepts. }\end{array}$ & 1.72 & 0.57 \\
\hline 6 & $\begin{array}{l}\text { In tests that I have NOT mastered, I feel that I did NOT fully understand } \\
\text { the corresponding concepts. }\end{array}$ & 2.89 & 0.96 \\
\hline 7 & $\begin{array}{l}\text { I feel that I put more effort into this course than I put into other courses } \\
\text { that I took this semester. }\end{array}$ & 2.44 & 0.86 \\
\hline 8 & $\begin{array}{l}\text { I think that the instructor was available to answer questions and assist } \\
\text { students. }\end{array}$ & 1.22 & 0.43 \\
\hline 9 & $\begin{array}{l}\text { I believe that my grade in this course accurately reflects my effort and my } \\
\text { understanding of course concepts. }\end{array}$ & 1.83 & 0.86 \\
\hline & I felt that course work was graded and returned in a timely manner. & 1.89 & 0.68 \\
\hline & I think that there were sufficient opportunities to retest when necessary. & 2.06 & 1.11 \\
\hline & $\begin{array}{l}\text { I would like to take another course in which this instructional method is } \\
\text { used. }\end{array}$ & 1.78 & 0.81 \\
\hline
\end{tabular}

Table 6: Student Survey with Summary of Responses

\section{Bibliography}

1 Wankat and Oreovicz, Teaching Engineering, McGraw-Hill, 1992

2 Phillips, Parr and Riskin, Signals, Systems and Transforms, 3rd Edition, Prentice Hall, 2003

3 Block, Mastery Learning: Theory and Practice, Holt, Rinehart and Winston, 1971

4 Block, Schools, Society and Mastery Learning, Holt, Rinehart and Winston, 1974

5 Stice, PSI and Bloom's mastery model: A review and comparison, Eng. Educ., 175 (1979)

6 Taveggia and Hedley, Teaching really matters, or does it?, Eng. Educ. 546 (1972) 